\begin{tabular}{|c|c|c|c|c|c|c|}
\hline \multirow{4}{*}{ Impact Factor: } & ISRA (India) & $=4.971$ & SIS (USA) & $=0.912$ & ICV (Poland) & $=6.630$ \\
\hline & ISI (Dubai, UAE & $=0.829$ & РИНЦ (Russia) & $=0.126$ & PIF (India) & $=1.940$ \\
\hline & GIF (Australia) & $=0.564$ & ESJI (KZ) & $=8.716$ & IBI (India) & $=4.260$ \\
\hline & JIF & $=1.500$ & SJIF (Morocco) & $=5.667$ & OAJI (USA) & $=0.350$ \\
\hline
\end{tabular}

\section{SOI: $1.1 /$ TAS $\quad$ DOI: $10.15863 /$ TAS \\ International Scientific Journal Theoretical \& Applied Science}

p-ISSN: 2308-4944 (print)

e-ISSN: 2409-0085 (online)

Year: 2020

Issue: 03

Volume: 83

Published: 30.03 .2020

http://T-Science.org
QR - Issue

QR - Article
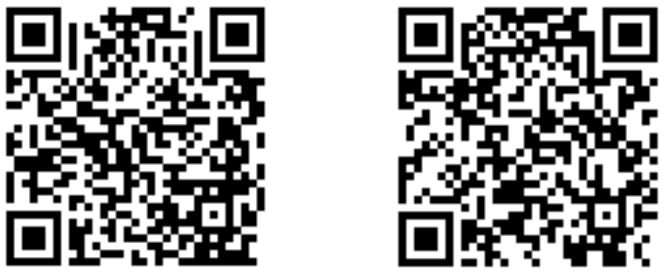

Komila Hasanovna Sayitova

The Bukhara Engineering and technological institute

A teacher of

Foreign Languages Department

\title{
USING TECHNIQUES AND METHODS OF THE CLIL SYSTEM IN THE PROCESS OF TEACHING ENGLISH
} \begin{abstract}
using CLIL methodology in a higher educational institution.
Language: English English. ISJ Theoretical \& Applied Science, 03 (83), 380-382.

Scopus ASCC: 1203.

\section{Introduction}

The processes of globalization, changes in all spheres of human activity are changing the requirements for higher professional education. The education system must meet the new requirements of society. As a rule, a teacher teaches only his subject, in isolation from all others. But this approach does not form the complex of knowledge that students must master for successful professional activities.

Therefore, new approaches to learning are needed. Scientists have confirmed the need to create fundamental pedagogical structures, the task of which will be to form a common culture of students, prepare for successful professional activities and develop a holistic worldview. The integrative approach, formed in the domestic and foreign methods, seems to be the most productive and effective in this regard. So, the structure of an integrative approach to teaching foreign languages will be considered here.
\end{abstract}

Abstract: the article deals with the role of the subject-language integrated teaching students of non-linguistic specialties of higher educational institutions. The main features of the work of the profile subject teachers and foreign languages teachers in the system of subject-language integrated teaching are considered. The prospects of its application in the sphere of higher professional education are also studied. There are given main peculiarities of

Key words: methodology of language-based integrated learning, professional communication, integrated training, integration, professional competence, foreign language for non-linguistic specialties.

Citation: Sayitova, K. H. (2020). Using techniques and methods of the clil system in the process of teaching
Soi: http://s-o-i.org/1.1/TAS-03-83-71

\section{II.Literature review}

Currently, the English language is of great importance in the system of intercultural communications of various peoples of the world - it is directly involved in the formation and development of cultural, educational, political and socio-economic ties in the international arena. The role of the English language in the process of integration of educational and scientific organizations into the world community has been noticeably growing lately [1,117]. In this regard, there is a need to use modern forms and methods of teaching a foreign language, which provide the most effective implementation of the training program, including scientific researchers.

\section{III.Analysis}

Modern requirements of training a graduate of a higher educational institution - a future specialist include not only a number of specific competencies, including: self-education, knowledge of innovative technologies, understanding the prospects and possibilities of their use, ability to make decisions independently, adaptability to new social and professional conditions, teamwork skills, ability to cope with stress, but also mastering one or more foreign languages in a high professional level $[2,182]$.

In most higher education institutions, according to the curriculum, intensive teaching of a foreign language (most often English) to students of nonlinguistic specialties ends in the third year, but it is 


\begin{tabular}{|c|c|c|c|c|c|c|}
\hline \multirow{4}{*}{ Impact Factor: } & ISRA (India) & $=4.971$ & SIS (USA) & $=0.912$ & ICV (Poland) & $=6.630$ \\
\hline & ISI (Dubai, UAE & $=0.829$ & РИНЦ (Russia) & $=0.126$ & PIF (India) & $=1.940$ \\
\hline & GIF (Australia) & $=0.564$ & ESJI (KZ) & $=8.716$ & IBI (India) & $=4.260$ \\
\hline & JIF & $=1.500$ & SJIF (Morocco) & $=5.667$ & OAJI (USA) & $=0.350$ \\
\hline
\end{tabular}

worth noting that, due to the lack of constant speech practice in the subsequent years of study, there is a gradual loss of communication skills. Therefore, there is a need to integrate a foreign language and professional disciplines throughout the entire period of study at the university, both for bachelors and masters.

Among teaching methods, including parallel teaching of both a foreign language and a specialized subject, we can distinguish the methodology of subject-language integrated learning (Content and Language Integrated Learning - CLIL), which can influence on the formation of the necessary competencies of technical, humanitarian and other students.

The term Content and Language Integrated Learning (CLIL) was introduced by the researcher in the field of multilingual education, David Marsh in the process of coordinating research on the state of language education in Europe in 1994 [4, 240]. This led to an all-European discussion, in which experts were representatives from Finland and the Netherlands. The issue of how to use the experience of advanced foreign language teaching, which was found in certain types of private schools, in the curriculum of public schools and colleges was discussed.

Now, after more than twenty years, the CLIL concept has become not only a way to gain access to additional languages, but also to introduce innovative practices in the curriculum integrally. CLIL as an approach is gradually being recognized in European countries. It seems that the trend in learning through the CLIL methodology will be more and more used in most European countries in the future $[3,6]$.

\section{IV.Discussion}

In 1994, the definition itself of subject-language integrated learning (CLIL) was also formed and approved: "Subject-language integrated learning or CLIL is a bidirectional competency-based approach to teaching, in which a foreign language is used to teach both the main subject and study the language itself " [3, p. 6].

Thus, CLIL integrates methods of teaching the subject and learning the foreign language itself. Using CLIL, students can study one or more subjects in a foreign language, often it is English. However, it is not assumed that students can initially speak a foreign language professionally before proceeding with the study of a specialized subject. They learn the language and specialized subject simultaneously.

Sophie Ioannou-Georgiou and Pavlos Pavlou confirm that among the features of the CLIL technique, the three main ones can be distinguished [3, 15]:

a) Learning a foreign language integrated into the content of the subject itself, such as science, history, geography. Students learn a foreign language through the facilitated content of the subject.

b) CLIL has its origin in various socio-linguistic and political contexts and concerns any language, age and level of education: from preschool, elementary to higher, vocational training. In this sense, CLIL meets all European educational programs intended for all citizens, where it is believed that multilingualism and multiculturalism contribute to the integration, understanding and mobility among peoples.

c) CLIL is an approach that involves the development of social, cultural, cognitive, linguistic, academic and other learning skills, which in turn contribute to the achievement in the field of study of both the subject itself and the language.

Out of foreign languages English is widely used at universities and institutes of many countries. In this regard, a large number of researchers in the field of integrated learning of the subject and language (CLIL) distinguish this technique as a unique way of studying several subjects simultaneously.

Integrated teaching of a subject and language at a higher educational institution is a developing field of theoretical and practical research, and there is no single established concept of how a higher educational institution should implement such training. Each higher educational institution has its own specifics, depending on which it makes decisions about ways and methods of teaching students in a foreign language [5, 258].

The methodology of teaching the subject within the framework of CLIL does not imply the strict use of language material (differing from studying a foreign language), therefore, the teacher has the opportunity to select language tools that, from his point of view, are best able to implement the substantial part of classes $[3,12]$.

\section{V.Conclusion}

In conclusion, we can say that subject-language integrated learning (CLIL) is a relatively new teaching methodology that can be considered as a unique way of teaching content through foreign language, as well as teaching a foreign language through content. This technique is of great interest to teachers of foreign languages, as well as to a number of teachers who master a foreign language and teach their major subject at a high school. Thus, combining two directions, specialist teachers are able to teach not only their major subject in a foreign language, but also use important training aids of a language: teach grammar, vocabulary, etc., including elements of a communicative methodology of teaching a foreign language in their lesson. This helps to simplify and modernize the curriculum at higher educational institutions. 


\begin{tabular}{|c|c|c|c|c|c|c|}
\hline \multirow{4}{*}{ Impact Factor: } & ISRA (India) & $=4.971$ & SIS (USA) & $=0.912$ & ICV (Poland) & $=6.630$ \\
\hline & ISI (Dubai, UAE & $=0.829$ & РИНЦ (Russi: & $=0.126$ & PIF (India) & $=1.940$ \\
\hline & GIF (Australia) & $=0.564$ & ESJI (KZ) & $=8.716$ & IBI (India) & $=4.260$ \\
\hline & JIF & $=1.500$ & SJIF (Moroce & $=5.667$ & OAJI (USA) & $=0.350$ \\
\hline
\end{tabular}

\section{References:}

1. Samoylova, Ye. V. (2014). Topical problems and teaching prospect of foreign language for non-linguistic university students in the network of the integrated approach / E.V. Samoylova, O.V. Nazarova, N.S Korniletskaya // Integration of education, №2.

2. Coyle, D. (2010). CLIL: Content and Language Integrated Learning / D. Coyle, Ph. Hood, D. Marsch // Cambridge University Press.

3. (n.d.). Ioannou Georgiou, Spfie and Pavlu, Pavlos:Guidelines for CLIL Implementation in Primary and Pre-primary Education [Electronic resource]/G. Ioannou // Comenius Socrates Project.

4. (n.d.). (accessed: 23.04.2017). Retrieved from http://www.schools.ac.cy/klimakio/Themata/An glika/teaching_material/clil/guidelinesforclilim plementation1.pdf

5. Mehisto, P. (2008). Uncovering CLIL: Content and Language Integrated Learning in Bilingual and Multilingual Education / P. Mehisto, D. Marsh, M. Frigols. Macmillan Oxford.

6. Marsh, D. (2002). The European Dimension: Actions, Trends and Foresights Potential]
[Electronic resource] / D. Marsh // Brussels: The European Union. - 2002. (accessed: 23.04.2017). Retrieved from http://userpage.fuberlin.de/elc/bulletin/9/en/marsh.html

7. Yarotskaya, L. V. (2016). Foreign language and formation of professional personality (nonlinguistic higher school). Monograph. Moscow: Publishing house TRIUMF.

8. (n.d.). Metodika prepodovanija inostrannih jazikov zarubezhom. "Progress"

9. Otaboyeva, M.R. (2017). Chet tilini o'qitishda zamonaviy innovatsion texnologiyalaridan foydalanish va uning samaradorligi. Molodoj uchenyj, №4.2, pp. 36-37. https://moluch.ru/archive/138/39058/

10. Ishmuhamedov, R. (2005). "Innovatsion texnologiyalar yordamida ta'lim samaradorligini oshirish yo'llari". Toshkent: "Nizomiy". TDPU.

11. Matmurotova, Z. (2017). Chet tillarni o`rgatish samaradorligini oshirish usullari. Molodoj uchenyj, №24.2, pp.37-38. https://moluch.ru/archive/158/44684 